\title{
Hispanic horror: An introduction
}

Ann Davies, University of Stirling

This issue of Horror Studies is dedicated to the theme of Hispanic horror, or horror texts that have some connection with cultures that can be considered to come under a Hispanic umbrella. The field has a long history that has often gone unnoticed, first because of horror's exile from the canon and the mainstream for many decades if not centuries, and second, because of the fact that many (although by no means all) Hispanic horror texts have been made in Spanish or, more rarely, languages connected with Spanish-speaking territories. This latter fact has made them less accessible to critique in the anglophone sphere, and greater awareness of them is long overdue.

Spain has long possessed a fine vein of the dark grotesque, epitomized by Goya's black paintings, while nineteenth-century authors such as Gustavo Adolfo Bécquer and Emilia Pardo Bazán consciously wrote Gothic tales without explicitly confessing that they were doing so. For the first half of the twentieth century horror and Gothic lay dormant, or appeared disguised as other genres or modes such as esperpento (a black form of the carnivalesque) and tremendismo ('a darkly pessimistic mode of realism based on deliberately crude representations of violence and crime, focusing on the morally and physically repellent') (Perriam et al. 2000: 74). Yet even though the political turmoil of much of the century, leading to the Spanish Civil War and the Franco dictatorship, were not propitious for the production of horror texts owing to censorship, Spanish horror began to become more prominent, particularly through the work of film directors such as Jess Franco, Narciso Ibáñez Serrador (who was particularly successful in bringing horror and sci-fi to Spanish TV screens in the 1960s) and Jacinto Molina. As Antonio Lázaro-Reboll documents, Spain 
underwent a horror boom between 1968 and 1975 (2012, Chapter 1). Since then, horror has proceeded in fits and starts, but has recently seen a strong upsurge in horror textual, visual and performative productions: niche publishers have sprung up, film production companies such as the Fantastic Factory became prominent and international mainstream success has been generated with Alejandro Amenábar's The Others (2001) and Carlos Ruiz Zafón's La sombra del viento (The Shadow of the Wind) (also 2001). In a parallel move to this rapid increase in primary texts, respectful critique has also grown exponentially. In the sphere of film, for instance, there were and are critics committed to the study of horror (and this despite its neglect in mainstream critique) (see Davies forthcoming): Carlos Aguilar and Ángel Sala in particular have long pioneered the study of Spanish horror film production and the industry and fan cultures that surround it. More recently, scholars in anglophone countries, primarily the United Kingdom, are increasingly turning their attention to Spanish horror. Lázaro-Reboll broke new ground with his monograph on Spanish horror film (2012), while Abigail Lee Six (2010) likewise opened the batting for Spanish Gothic. Andy Willis's work has also been crucial in helping to set parameters and definitions (such as his seminal article of 2004), while Xavier Aldana Reyes has published the first history of Spanish Gothic, covering both literature and film (2017). Spain-based critics, meanwhile, have wrestled with the labels of horror and Gothic as potentially an imposition from anglophone criticism, and instead a body of work has grown that emphasizes the fantastic as opposed to horror, spearheaded by the Grupo de Estudios sobre lo Fantástico. I return briefly to the debate over labelling below.

Latin American horror and Gothic maps itself differently, particularly since here we are talking about a continent, with countries that have undergone differing sociopolitical processes. Latin America has nonetheless a common history in that it was widely perceived as a source of real-life horror and monsters, as documented by G. Eljaiek-Rodríguez (2018) and Persephone Braham (2015), among others. As the latter observes, the fetishization of 
monsters within Latin America was also taken up by its own intellectuals: 'In numerous debates on Latin America's character and future, monsters are held forth as metaphors for a series of problems ranging from indigenous and African slavery to dictatorship and postcolonial identity'. Only recently has there arisen a sense of monsters as a global rather than national phenomenon: 'a postnational awareness that effectively returns monsters to their places of origin' (2015: 2). Latin American literary life was also susceptible to European and, later, US influence, and from the early nineteenth century translations of Gothic works from these territories began to appear and infiltrate Latin American literature (Eljaiek-Rodríguez 2014: 13-14). Horror and Gothic elements in twentieth-century literature tended to take a critical back seat in favour of Latin America's strong association with magical realism, but Gothic at least came back into view with the concept of tropical Gothic, which becomes, as Eljaiek-Rodríguez notes, 'synonymous with Latin America as a whole - not only the humid Caribbean - taking into account that Latin American writers and directors deliberately tropicalize European and South American characters, be it as a critique or as a way of autoexotization' (2014: 14). Horror cinema also maintained a presence in Latin America: in the Mexican case, for example, horror films appeared as part of the first wave of sound pictures in the 1930s (see Rhodes 2003), has oscillated in prominence but has also played its part in blurring national boundaries, above all with the towering presence of Guillermo del Toro (whose own work has firm roots in horror traditions but subsequently crosses genre boundaries into fantasy and sci-fi). Del Toro was not the first director to play fast and loose with national boundaries, however: this characteristic is one of a few that he shares with the earlier work by Alejandro Jodorowsky, not least distance and distaste on the part of the Mexican government's cultural mandarins (see Keesey 2003).

In contemporary Latin America today, Gustavo Subero notes that 
A quick glance at Latin American filmic production since the turn of the twenty-first century clearly evidences a resurgence of horror films that indicates both a departure from the socially committed filmic agendas that had characterised cinema since the advent of the New Latin American Cinema movement, and a desire to embrace more commercial filmic genres as valid vehicles to explore notions of national, sexual and cultural identity. By the same token, academics have also realised the importance of the horror genre to exploring issues related to identity formation and to conveying or challenging the status quo of culture in a specific milieu. (2016: xxiii)

However, the reception of horror may differ within and outwith the Hispanic world, and the Latin American case in particular demonstrates the difficulties. Dolores Tierney studies the use of the term 'cult' to encompass horror, trash and exploitation films, observing that 'With most Latin American films that have become the object of cult consumption, most- Englishlanguage scholarship is talking about audience from outside Latin America'. She refers to Jodorowsky's cult classic El Topo (The Mole) (1970) to argue that its 'subcultural value relies on its “otherness" to an Anglo or European audience' (Tierney 2014: 131). She goes on to argue for Latin America's strong cult production that nevertheless does not use the term 'cult' to describe itself (2014: 134). She concludes that:

What remains for scholars of Latin American cinema interested in further work in this area $[\ldots]$ is to determine how this work [of research into Latin American cult history] may progress without reifying the problematic clichés of a peripheral cinema and a peripheral continent. (2014: 135) 
Tierney's comments serve as an introduction to the difficulties of definition and positing that comes with a label of Hispanic horror.

The word 'Hispanic' as used here is generally a broad one that focuses in the first instance on horror texts and production in the Spanish language and emanating from Spain, Latin America or other Spanish-speaking communities. It is nonetheless an ambiguous term. It is a term that also overlaps with notions of otherness, which in turn, as Gabriel Eljaiek-Rodríguez has observed, feeds into notions of horror, the Gothic and monstrosity. He comments that 'being Latin American can be read as synonymous with being an other - at least in relation with colonial or metropolitan powers that imposed their specific cultures in detriment of plural societies' (2018: 14). This is a concept that has also applied to Spain specifically, as part of an 'other', more primitive Europe in contrast to Northern European countries and France in particular. And Spanish horror film, too, has offered similar counter-cultural pleasures for audiences abroad as Jodorowsky's El Topo has. More specifically, the term 'Hispanic' also has ethnic connotations, particularly in the United States, where it is often, and problematically, associated with immigration from Latin American countries and used as a marker of non-white racial identity - a usage that elides people and identities deriving specifically Spain and that can be confusing when seen from a UK/European perspective. (An example of this is the actor Penélope Cruz, understood as Hispanic and thus not white in the American context [see Davies 2014: 68-69]: I have taught on the subject of Cruz to UK and European students, who are all bemused that Cruz is not seen as white). In approaching this label, then, the reader should take into account my own explicit standpoint: that, although understanding that others might use the term differently, my own, UK-orientated, approach is based on the association of Hispanic primarily with the Spanish language and, following that, a strong association with those territories where Spanish is a key or even dominant language. (This would not preclude other languages and identities coming into play within this remit, as 
for example questions of Catalan identity in opposition to Spanish identity, as addressed in McKeown's article in this issue, or indeed the fact that Hispanic film directors may work in other languages, particularly English). The authors of this special issue likewise do not use the term 'Hispanic' in a simplistic way: they may avoid the term altogether by referring to specific national or territorial origins such as Spain or Latin America, or regional identities such as the Canaries or Catalonia, or by an explicit association of the term with language. Reference to the Hispanic in this introduction, however, is retained both for the practical purposes of reference (listing all the possible territories that might be associated with the term can be tedious for the reader) but also a tacit and sometimes explicit recognition that Hispanic identity is a fluid one that forms part of a global cultural flow. Ordiz, Lee Six and Davies refer to this flow in different ways in their contributions here.

Horror, too, becomes a complex term in the Hispanic context, existing on a spectrum that is often contested. Threading through the debate on the appropriate terms to use in the Hispanic context is precisely the fear of reification that Tierney points out above: within Spain and Latin America some critics fight shy of labels that might be perceived as imposed from outside. In Spain, the term 'Gothic' in particular is sometimes avoided as a label deriving from anglophone contexts and thus inappropriate as a frame within which to discuss Spanish texts, while horror is also a term some critics prefer to avoid. Miguel Carrera Garrido (2018) reviews the debate between the often preferred term of the fantastic (lo fantástico or lo insólito) and horror, arguing for a distinction between horror and the fantastic that rests on the former's disruption of normality rather than of the real (2018: 8). In the Latin American context, horror and Gothic have for a long while been neglected in favour of magical realism and to a lesser extent the fantastic (see, e.g., Ordiz and Casanova-Vizcaíno 2017, for a challenge to this position). These debates highlight a dilemma in who has the authority over definition, and what insights from different theoretical frameworks might be lost in 
consequence. In practice, of course, academics will generally go their own way with the frameworks that they prefer, but disputes over definitions nonetheless compel them to think what their particular standpoint is and to take into account the definitions of others. In the case of this special issue, no specific definition has been imposed: contributors have been free to interpret the word 'horror' and its surrounding discourse as they have preferred, and by and large they have left this debate well alone. It is important to recognize here, however, that such a debate exists, particularly for those who might be new to Hispanic horror and have hitherto been unaware of the nuances of definition as they exist in the Hispanic case, which might lead authors to write about something to which the reader would assign a different label.

A different risk in focusing on non-anglophone horror is one of parochialism, or of reading a Hispanic horror text solely in terms of a national sociopolitical context while neglecting other readings. This is a problem that has, for instance, affected interpretations of contemporary ghost stories within Hispanic Studies. Taking Spain as an example, many Hispanists automatically reach for an interpretation that understands ghosts as symbolic of those who died or disappeared during the Spanish Civil War (1936-39) and the ensuing Franco dictatorship (1939-75), and ignore other possible readings that tie in to common frameworks within horror (such as gender, the role of the child and intertextual references from horror worldwide). Interpretations in terms of national traumas follow the theorizations of Adam Lowenstein (2005) and Linnie Blake (2008), but there is an inherent danger of insular readings that treat the text as only a veneer for the territory lying underneath, so that a novel or a film can only be about 'Spain', 'Mexico' and so on, and can never be about anything else. This obscures the role that other elements can play, not least of them pleasure (Davies 2019). So Ordiz, in her analysis on the influence of Stephen King on horror literature in Spain and Latin America in this special issue, draws attention to the fact that authors take King as a 
seminal influence that is not necessarily context dependent, even as they often (but not always) reinterpret his influence in the light of their own geopolitical situations. Davies and Lee Six in this issue place vampire texts within the context of Spain but understand these texts as part of a wider vampiric continuum. For these authors, outside influence is something to be appreciated, even celebrated, and not disparaged. Nonetheless we must also acknowledge concerns that Hispanic horror can only be seen as part of a universal and transnational horror that is in practice specifically anglophone by default if not by design. The complex negotiations oscillating between these two poles of local and global is of crucial import not only within Horror Studies but within cognate disciplines such as Hispanic studies, although the latter can take some encouragement from the fact that the horror genre has long pioneered an international approach, particularly as regards film, and horror audiences embrace a wide and eclectic range of texts from varying provenances, wherein the primary point of connection is by and large not so much where the text comes from as what story it has to tell us.

It is therefore these flows with which we begin this special issue. Inés Ordiz examines the implications of Hispanic horror in a global context by taking the work of canonical horror writer Stephen King as a pivotal point of influence within Spanish and Latin American Gothic and horror writing. King's influence is not to be seen as unidirectional or as an instance of cultural imperialism: instead, as Ordiz argues, the adoption within Spanish or Latin American literature of Kingian motifs should be perceived as creative local adaptations that are nonetheless part of a global flow, a flow from which King himself has drawn on occasion. After reviewing the debate concerning cross-cultural Gothic and horror in the Hispanic context, and the specific impact that King's work has had on Hispanic literary production, she proceeds to study specific instances of this particular strand of cross-cultural fertilization. She first turns to religious themes and motifs in the narratives of Mariana 
Enríquez, Fernando Iwasaki and Nicolás Saraintaris, who draw on King's figure of the herochild as pivotal to the stories that they tell. She then moves on to a very familiar Kingian motif, again centred round the child: the Grady sisters of The Shining, as refigured in the work of by Patricia Esteban Erlés and Espido Freire. She concludes that 'Tropes of King's fiction become global cultural artefacts that are creatively appropriated, honoured and, through translation into English, re-inserted in the flow of global circulation of culture, ensuring that the traffic in characters and tropes is not unidirectional'.

This special issue has two articles dedicated to the vampire, and this is noteworthy, given the comparative paucity of vampire texts in Spain in particular, Latin America faring somewhat better in this respect. Abigail Lee Six explores the changes in the meaning of the term 'vampire' and its close relation 'vamp' to trace how meanings shifted in the first few decades of twentieth-century Spain. She points to another international referent, the original 'vamp' Theda Bara, to suggest how Bara's star persona influenced a shifting definition that slid between the idea of women as sexual predators and the bloodsucking creature we are more familiar with today. She studies short stories by two authors, Antonio de Hoyos y Vinent and Carmen de Burgos, effecting a comparison that allows the gendered implications of the vamp/vampire dialectic to stand out in strong relief. For both authors, the female vamp(ire) is described from the point of view of the male narrator, who perceives her as parasitical and life-draining. De Burgos, however, goes beyond de Hoyos y Vinent to offer the vamp(ire)'s perspective as well, allowing for a more sympathetic perspective. Milly Williamson (2005) discussed how the notion of the sympathetic vampire as dating from before the 1980s and the 1990s with which such a move is popularly associated: de Burgos's tales offer another example of how right Williamson was to point this out.

One reason why Spain might be lacking its vampires could be its strong (if not wholly accurate) association with sunshine (see Davies 2015). Rhian Davies addresses precisely this 
question of sunlight as part of her analysis of Miguel Aguerralde's Noctámbulo (Night Owl) (2010), set in the Canary Islands. The international fluidity of the vampire that Lee Six noted in her own article reappears here but in new forms: the suggestions of sympathy have now become much pronounced, and the permutations on vampirism so varied that a vampire in a predominantly sunny terrain by now seems eminently reasonable. Davies argues that the Canarian setting reflects sociopolitical concerns about corruption at the time of the novel's publication, concerns that are duly translated into a criminal context within which the novel's vampire operates. But more specifically, Davies also addresses the othering of the Canarian context as remote from the Spanish mainland and thus often marginalized, particularly in terms of debates over Spanish national memories of the Civil War. In this way, Davies concludes, the novel offers us a transnational vampire that speaks to (and happily contradicts) many of the circulating conventions of vampire texts: at the same time, however, Aguerralde also applies these to the specificities of the Canary Islands in a manner reminiscent of the ways in which, as Ordiz has traced, Hispanic authors treat the influence of King - that is, as both deterritorializing and reterritorializing. In addition, Aguerralde also points to the fact that othering can be multi-layered: if Spain itself is considered an outlier in terms of vampire texts, then a Canarian vampire is further othered owing to his position on the periphery of Spanish cultural and political discourse.

Will McKeown takes a Lacanian approach to his discussion of Jaume Balagueró and Paco Plaza's highly successful [REC] (2007), but his argument does not dodge the matter of the specific geopolitical context in which the film is set, and his later discussion takes up a different case from Davies concerning othering within Spanish political discourse. The primary focus of McKeown's discussion is what he terms the chain of self-sacrifice, that is, the role played by characters who must die in the course of action so that other characters might survive. McKeown's analysis of the chain of self-sacrifice is one that has wider 
application to horror texts irrespective of the historical and geographical situation. The idea of self-sacrifice is key to many horror texts, particularly slasher thrillers or, as here, zombie infections, which imply a serial procession of victims in which audiences are likely to know in advance that some characters will be sacrificed to satisfy the demands of the genre. Moreover, the involvement of authority figures as self-sacrificial offerings points to the complex and problematized position of such figures within horror. And as I mentioned above, it is important not simply to reduce Hispanic horror to nothing but its context: these texts are not simple replications of Hispanic territories but form part of - and indeed contribute to worldwide academic debate and theorization of horror. Nonetheless, McKeown also goes straight to one of the particularly sore points of identification within Hispanic horror wherein Hispanic identity clashes or fragments. The film's Barcelona setting evokes the tense relationships between Catalan identities, which can only problematically be contained within a Hispanic remit, and the Spanish state, the latter corralling the hapless occupants of the infected house while remaining all powerful and unseen. McKeown's essay thus performs a double function in siting horror discourse both within and outwith the Hispanic sphere, and encourages us to move beyond the parochial while nevertheless retaining some links to the local.

Finally, Miguel Carrera Garrido concludes this special issue with a focus on one of the more neglected media within horror and Gothic: the theatre. Carrera Garrido looks at the specific case of immersion theatre as part of a wider neglect of horror theatre in the Spanish context. As he points out, audience involvement in immersion theatre comes closer to an experience of horror than film and literature do, and to this end he studies the specific case of the Factoría de Terror ('Factory of Horror'). After outlining the role of immersive theatre in generating horror, he considers the founding aims and principles of Factoría de Terror as they develop over time, including the role of space and the balance between scripting and 
improvisation, before focusing more specifically on the group's Experimento Fear 2.0 (Experiment Fear 2.0). The conclusion of his study is that immersive horror theatre is crucial for its capacity to offer the spectator agency, which opens up new possibilities for our understanding of horror. Carrera Garrido places his discussion of the Factoría de Terror within an understanding of horror theatre and related media that does not recognize boundaries: immersive horror has its parallel practices worldwide. The work of Zoraida Marín, the founder of Factoría de Terror, is nonetheless also local, forming part of the theatrical fringe in Spain, particularly Madrid, and with this contrast we come full circle, with Ordiz's understanding of horror in terms of deterritorialization and reterritorialization, the difference now that the deterritorialized dimension is played down in favour of the here and now, and of agency in real time.

As the following articles will reveal, Hispanic horror is not reductively representative of nations, regions or ethnicities, but operates as part of a transnational ebb and flow that nonetheless takes on local interpretations. It does not function simply as a passive recipient, absorbing outside influences, but speaks back to these influences as active contributors to this cultural ebb and flow. Eljaiek-Rodríguez (2018: 16) notes that: 'What at first glance might look like a transliteration is in fact part of an active effort to represent those domestic political and social horrors whose depth demands transnational resources in order to find adequate expression'. He goes on to note that migration does not merely encompass people or money but also 'intangible cultural products such as images, tropes, themes' (2018: 16). Hispanic identities have of late been troublingly associated with migration: the reach of Hispanic cultures through cuisine, music, fashion and the like has also extended far. And with this the reach of the intangibles that Eljaiek-Rodríguez refers to becomes both more pervasive and persuasive. To return, finally, to Tierney's concerns about standpoints: the authors of this special issue come from both inside and outside the Hispanic world, but all have a clear 
connection and passion to it, and reveal an understanding of how Hispanic horror itself is positioned to look both inwards and outwards. It is this appreciation from both inside and out that will facilitate Hispanic horror escaping its niche position while nonetheless recognizing its roots in the local and the global.

\section{References}

Aguerralde, Miguel (2010), Noctámbulo, Santa Cruz de Tenerife: Ediciones Idea

Aldana Reyes, X. (2017), Spanish Gothic: National Identity, Collaboration and Cultural Adaptation, London: Palgrave Macmillan.

Amenábar, Alejandro (2001), The Others, Spain/USA/France/Italy: Cruise/Wagner Productions/Sogecine/Producciones del Escorpión.

Balagueró, Jaume and Paco Plaza (2007), [REC], Spain: Castelao Producciones/Filmax/Instituto de la Cinematografía y de las Artes Audiovisuales

Blake, L. (2008), The Wounds of Nations: Horror Cinema, Historical Trauma and National Identity, Manchester: Manchester University Press.

Braham, P. (2015), From Amazons to Zombies: Monsters in Latin America, Lewisburg: Bucknell University Press. 
Carrera Garrido, M. (2018), 'Fantástico y terror: teoría y práctica de dos categorías ficcionales en el ámbito hispánico', Studia Romanica Posnaniensia, 45:2, pp. 5-20.

Davies, A. (2014), Penélope Cruz, London: British Film Institute and Palgrave Macmillan. (2015), - 'Gothic Sunshine: Spanish Film and the Creep Factor of the Full Light of Day', The Gothic Imagination (6 March) http://www.gothic.stir.ac.uk/blog/gothic-sunshinespanish-film-and-the-creep-factor-of-the-full-light-of-day/. Accessed 30 July 2019.

(2019), 'Pleasure and historical memory in Spanish Gothic film', Bulletin of Hispanic Studies, 96:4, pp. 397-411.

(forthcoming), 'The queer Gothic regime of La residencia', in A. Lema-Hincapié and C. Domenech (eds), Indiscreet Fantasies: Iberian Queer Cinema, Bucknell University Press.

Eljaiek-Rodríguez, Gabriel (2014), 'Semillas de maldad: Early Latin American Gothic', Studies in Gothic Fiction, 3:2, pp. 13-23, https://studiesingothicfiction.weebly.com/uploads/2/2/8/8/22885250/sgf_3.2_final.pdf. Accessed 2 July 2019. (2018), The Migration and Politics of Monsters in Latin American Cinema, Cham: Palgrave Macmillan. 
Jodorowsky, Alejandro (1979), El Topo, Mexico: Producciones Panicas.

Keesey, P. (2003), 'Madmen, visionaries and freaks: The film of Alejandro Jodorowsky', in

S. J. Schneider (ed.), Fear Without Frontiers: Horror Cinema Across the Globe, Godalming: FAB Press, pp. 15-25.

Kubrick, Stanley (1980), The Shining, UK/USA: Warner Bros/Hawk Films/Peregrine.

Lázaro-Reboll, A. (2012), Spanish Horror Film, Edinburgh: Edinburgh University Press.

Lee Six, A. (2010), Gothic Terrors: Incarceration, Duplication, and Bloodlust in Spanish Narrative, Lewisburg: Bucknell University Press.

Lowenstein, A. (2005), Shocking Representation: Historical Trauma, National Cinema, and the Modern Horror Film, New York: Columbia University Press.

Ordiz, I. and Casanova-Vizcaíno, S. (eds) (2017), 'Introduction: Latin America, the Caribbean, and the persistence of the Gothic', in Latin American Gothic in Literature and Culture, New York: Routledge, pp. 1-12.

Perriam, C., M. Thompson, S. Frenk and V. Knights (2000), A New History of Spanish Writing: 1939 to the 1990s, Oxford: Oxford University Press. 
Rhodes, G. R. (2003), 'Fantasmas del cine mexicano: The 1930s horror film cycle of Mexico', in S. J. Schneider (ed.), Fear Without Frontiers: Horror Cinema Across the Globe, Godalming: FAB Press, pp. 93-103.

Ruiz Zafón, Carlos (2001), La sombra del viento, Barcelona: Planeta.

Subero, G. (2016), Gender and Sexuality in Latin American Horror Cinema, London: Palgrave Macmillan.

Tierney, D. (2014), 'Mapping cult cinema in Latin American film cultures', Cinema Journal, 54:1, pp. 129-35.

Williamson, M. (2005), The Lure of the Vampire: Gender, Fiction and Fandom from Bram Stoker to Buffy, London: Wallflower.

Willis, A. (2004), 'From the margins to the mainstream: Trends in recent Spanish horror cinema', in A. Lázaro-Reboll and A. Willis (eds), Spanish Popular, Manchester: Manchester University Press, pp. 237-49. 